\title{
DESAIN USER INTERFACE INFORMASI PRODI DESAIN KOMUNIKASI VISUAL MELALUI MEDIA DIGITAL WEBSITE
}

\author{
Dedit Priyono, Ahmad Ramdhani, Robby Hardian \\ Program Studi Desain Komunikasi Visual \\ Politeknik Harapan Bersama Tegal
}

\begin{abstract}
Abstrak. Sebagai Program Studi baru, DKV Politeknik Harapan Bersama Tegal belum mempunyai media informasi yang dapat menampilkan informasi kegiatan akademik. Perkembangan teknologi berdampak kepada peningkatan kualitas desain website dalam memenuhi kebutuhan pengguna dalam mengakses website melalui berbagai perangkat dan komputer desktop. Kemudahan ini berakibat kepada proses desain yang memberikan pengalaman yang mengesankan bagi pengunjung yang membuka website tersebut. website dikatakan baik apabila mampu menciptakan berbagai pengalaman dalam lingkungan internal maupun eksternal bagi pengguna dan memiliki peranan penting dalam perancangan desain website. Hal ini dikarenakan rancangan design sangat erat kaitannya dengan User Interface dan User Experience sehingga dapat dijadikan tolak ukur website dalam mencapai tujuannya. Perancangan informasi prodi berbasis website mencoba menerapkan tampilan antarmuka website yang lebih menarik dan sesuai dengan kebutuhan pengguna. Penelitian ini merupakan penelitian mix method dengan pendekatan User-Centered Design. Sampling menggunakan purposive sampling dengan mengambil beberapa perwakilan mahasiswa setiap kelas. Pengambilan data dilakukan dua kali, pengambilan data pertama menggunakan Focus Grup Discussion (FGD). Masukan dari FGD tersebut dijadikan pertimbangan untuk dijadikan konten, pengambilan data kedua sebagai uji coba prototype website. Dari tiga aspek yang diujikan secara keseluruhan masing-masing aspek masuk dalam kategori "Baik" dengan nilai prosentase 75,94\%, untuk aspek Konten dan organisasi, 77,21\% untuk aspek navigasi dan tautan, $77,71 \%$ untuk aspek visual.
\end{abstract}

Kata kunci : Prodi DKV, User Interface, Media Digital, Website

\begin{abstract}
As a new Study Program, DKV Polytechnic Harapan Bersama Tegal doesn't have any information media that can announce academic information. Technological developments have an impact on improving quality of website design for user's needs in accessing websites through various devices and desktop computers. This simplicity results in a design process that provides a memorable experience for visitors who open the website. A well-approved website offers users experience in both internal and external environments and has an important role in website design. This is because the design that is designed is closely related to the User Interface and User Experience so that it can be used to measure the website in achieving success. Design of web-based study program information tries to put on a web interface that is more attractive and suits the user's needs. This research is a mixed methods research using User-Centered Design. Sampling uses purposive sampling by taking several student representatives for each class. Data retrieval is done twice, first data collection using Focus Group Discussion (FGD). FGD result is to create captured content, retrieve data to test prototype websites. Of the three aspects tested, each aspect falls into the "Good" category with a percentage value of $75.94 \%$, for the Content and organization aspects, $77.21 \%$ for the navigation and link aspects, $77.71 \%$ for the visual aspects.
\end{abstract}

Keywords : Prodi DKV, User Interface, Digital Media, Website

Correspondence author: Dedit Priyono, belozoglu.dt@gmail.com, Tegal, Indonesia 


\section{Pendahuluan}

Program Studi Diploma III Desain Komunikasi Visual (DKV) merupakan salah satu program studi baru di Politeknik Harapan Bersama Tegal yang disahkan pada tanggal 31 Desember 2018. Berdasarkan izin penyelenggaraan dari Kemristek Dikti Wilayah Kopertis VI dengan Nomor SK Pendirian 1298/KPT/1/2018 tentang rekomendasi penambahan program studi D III Desain Komunikasi Visual (DKV) di Politeknik Harapan Bersama. Prodi DKV berupaya membangun manajemen prodi yang diharapkan akan meningkatkan mutu pendidikan dan memberikan pelayanan akademik dengan maksimal terhadap mahasiswa/mahasiswi Program Studi Desain Komunikasi Visual (DKV) Politeknik Harapan Bersama.

Sejak mulai kegiatan akademik dan perkuliahan mahasiswa baru tahun pelajaran 2019/2020, beberapa mahasiswa merasakan kebingungan dan kesulitan dalam mendapatkan informasi-informasi akademik Prodi DKV, mahasiswa mendapatkan informasi akademik prodi dkv hanya dari layanan chat grup dari salah satu media sosial. Tidak hanya itu admin Prodi dkv juga mengalami kerepotan membalas pertanyaan beberapa mahasiswa menanyakan ulang informasi akademik yang sudah disebar lewat grup chatting medsos, admin prodi menjelaskan alasan menanyakan ke admin karena kiriman informasi yang disebar lewat grup chatting sudah tenggalam dengan karena komentar-komentar dari mahasiswa lainnya sehingga susah dicari.

Teknologi yang semakin berkembang saat ini juga memudahkan masyarakat untuk memperoleh informasi secara instan. Mereka dapat dengan mudah mengakses berbagai informasi melalui website. Menurut Yuhefizar (159) website didefinisikan sebagai suatu metode untuk menampilkan sebuah informasi di Internet. Informasi yang dimaksud mencakup teks, gambar, suara, maupun video yang interaktif dan berkaitan dengan dokumen lainnya sehingga dapat saling terhubung dan diakses melalui browser.

Perkembangan teknologi sekarang ini berdampak kepada peningkatan kualitas desain website dalam memenuhi kebutuhan pengguna dalam mengakses website melalui berbagai perangkat dan komputer desktop (Landa dalam Kuswanto). Kemudahan ini berakibat kepada proses desain yang memberikan pengalaman yang mengesankan bagi pengunjung yang membuka website tersebut. Website disebut menarik apabila memiliki elemen yang saling berkaitan antara satu sama lain (Beaird). Selain itu Miller menyatakan bahwa website dikatakan baik apabila mampu menciptakan berbagai pengalaman dalam lingkungan internal maupun eksternal bagi pengguna dan memiliki peranan penting dalam perancangan desain website. Hal ini dikarenakan rancangan desain sangat erat kaitannya dengan User Interface dan User Experience sehingga dapat dijadikan tolak ukur website dalam mencapai tujuannya

User Interface (UI) merupakan bagian dari pembelajaran Human Computer Interaction ( $\mathrm{HCl})$ dalam mempelajari rancangan dan mendesain bagaimana manusia dan perangkat komputer mampu bekerjasama sehingga kebutuhan dapat terpenuhi secara efesien dan efektif (Galitz). UI dapat dilakukan melalui sentuhan, penglihatan, pendengaran, komunikasi dua arah, dan memahami secara langsung. Menurut Galitz UI memiliki dua komponen utama, yaitu Input dan Output. Yang termasuk di dalam Input antara lain keyboard, mouse, touch screen, dan instruksi melalui suara; sedangkan yang termasuk di dalam output adalah hasil yang didapatkan komputer berdasarkan perintah yang diberikan oleh pengguna. Adanya hubungan antara keduanya merupakan komponen utama dalam menjalankan sistem dengan baik dalam hal ini UI. Oleh karena itu UI merupakan perantara bagi pengoperasian perangkat keras (hardware), perangkat lunak (software), dan manusia (brainware). Hal ini sesuai dengan Galitz yang menyatakan bahwa UI merupakan komponen dari sistem yang dapat dilihat, didengar, dan disentuh tanpa adanya kesulitan dalam pengoperasian sistem. 
Sedangkan User Experience (UX) merupakan berbagai aspek dalam menggunakan produk intraktif dalam memahami cara kerja dan tujuan dari menggunakan produk tersebut yang sesuai dengan kebutuhan pengguna. Seperti yang dijelaskan menurut Alben dalam Rahmasari and Yanuarsari bahwa User experience adalah semua aspek tentang bagaimana seorang pengguna menggunakan produk interaktif, seberapa mudah mereka memahami cara kerjanya, bagaimana perasaan mereka ketika menggunakannya, dan bagaimana pencapaian tujuan mereka dalam menggunakan produk ini. ada beberapa tahap yang perlu diperlukan menurut Soverini Sembilan tahap pengerjaan UX (UX Project List) tersebut adalah seperti pada tabel di bawah ini:

Tabel 1. User Experience Project List Soverini (2018)

\begin{tabular}{|c|c|c|}
\hline No & Tahap & Proses \\
\hline \multirow{3}{*}{1} & \multirow{3}{*}{ Research } & Competitive Analysis \\
\hline & & Data Analysis \\
\hline & & User Feedback \\
\hline \multirow{3}{*}{2} & \multirow{3}{*}{ Plan } & User Stories \\
\hline & & User Flows \\
\hline & & Red Routes \\
\hline \multirow{3}{*}{3} & \multirow{3}{*}{ Explore } & Brainstorm \& Sketch \\
\hline & & Wireframe \\
\hline & & Prototype \\
\hline \multirow{3}{*}{4} & \multirow{3}{*}{ Communicate } & $\begin{array}{l}\text { IA (Information } \\
\text { Architecture) }\end{array}$ \\
\hline & & Leanguage \\
\hline & & Accessbility \\
\hline \multirow{4}{*}{5} & \multirow{4}{*}{ Create } & UI Elements \\
\hline & & Gestures \\
\hline & & Responsiveness \\
\hline & & Test \\
\hline
\end{tabular}

\begin{tabular}{|c|c|c|}
\hline No & Tahap & Proses \\
\hline \multirow{3}{*}{6} & \multirow{3}{*}{ Give Feedback } & Waiting Times \\
\hline & & Errors \\
\hline & & Completed Actions \\
\hline \multirow{3}{*}{7} & \multirow{3}{*}{ Finalise } & Finalise Layout \\
\hline & & $\begin{array}{l}\text { Use of images and } \\
\text { icons }\end{array}$ \\
\hline & & $\begin{array}{ll}\begin{array}{l}\text { Font \& Colours } \\
\text { Hierarchy }\end{array} & \\
\end{array}$ \\
\hline \multirow{3}{*}{8} & \multirow{3}{*}{ Delight } & Micro Copy \\
\hline & & Micro Interactions \\
\hline & & Transsitions \\
\hline \multirow{3}{*}{9} & \multirow{3}{*}{ Analyse } & KPI Setup \\
\hline & & $A B$ Test Plan \\
\hline & & Test \\
\hline
\end{tabular}

Dari 9 tahapan yang disebutkan, seringkali para desainer mengabaikan tahapan Delight, tahapan delight menurut Soverini dalam Fakhruddin et al. adalah menyiapkan emotional desain dan interaksi-interaksi kecil seperti Micro Copy, Micro Interactions dan Transtion yang bertujuan untuk mendorong keterlibatan pengguna dan menciptakan pengalaman yang baik oleh pengguna. Hal tersebut sejalan dengan yang dijelaskan oleh Saffer Microinteractions: Designing with Details bahwa para desainer menggunakan design thinking hanya untuk fokus terhadap perancangan elemen-elemen visual yang dibutuhkan pada desainnya, sehingga salah satu bagian yang terpenting dari desain itu benar-benar tidak ada, bagian detail itu adalah delight (menyenangkan). Saffer juga menjelaskan tahapan ini adalah yang seharusnya dapat dikerjakan oleh para desainer dengan baik, salah satu cara untuk menciptakan pengalaman yang menyenangkan ke pengguna. Senada dengan Batchu bahwa interaksi-interaksi kecil seperti micro interactions dapat menambah detail pada website dan membuat website tersebut berbeda dengan yang lain. 
Menanggapi permasalahan tersebut, diperlukan sebuah inovasi yang dapat membungkus informasi Program Studi DKV Politeknik Harapan Bersama Tegal menggunakan tampilan antarmuka website yang lebih menarik dan sesuai dengan kebutuhan pengguna.

\section{Metode}

Penelitian ini merupakan penelitian terapan dengan menggunakan mix method (kualitatif dan kuantitatif) dengan pendekatan User-Centered Design. Pendekatan User-Centered Design menurut Saffer Designing for Interaction: Creating Smart Applications and Clever Devices (Voices That Matter) adalah pendekatan yang lebih menekankan terhadap kebutuhan pengguna dan tujuan yang ingin dicapai dengan menggunakan produk tersebut, dalam hal ini pengguna memberikan panduan utama terhadap rancangan desain dan desainer yang bertugas untuk menterjemahkan kebutuhan dan tujuan pengguna tersebut. Rangkaian penelitian ini mencakup dua tahap, yaitu tahapan penelitian dan perancangan.

Tahapan Penelitian mencakup proses pengumpulan data hingga analisis data. Pengumpulan data dalam penelitian ini dilakukan dengan observasi, studi literatur, dan FGD (Focus Grup Discussion). Responden yang akan diambil untuk mendapatkan data terkait informasi yang dibutuhkan adalah mahasiswa baru Program Studi DKV Politeknik Harapan Bersama Tegal, pengambilan responden menggunakan teknik purposive sampling dengan mengambil beberapa perwakilan mahasiswa pada masing-masing kelas.

Tahap perancangan adalah dengan menggunakan metode Design Thingking, metode Design Thinking menurut Razi et al. adalah metode yang dikenal sebagai suatu proses berfikir komperehensif yang berkonsentrasi untuk menciptakan solusi yang diawali dengan proses empati terhadap suatu kebutuhan tertentu yang berpusat pada manusia (human centered) menuju suatu inovasi berkelanjutan berdasarkan kebutuhan penggunanya. Design Thingking

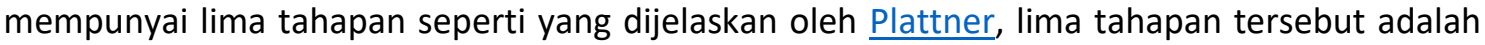
Emphatize, Define, Ideate, Prototype, Test.

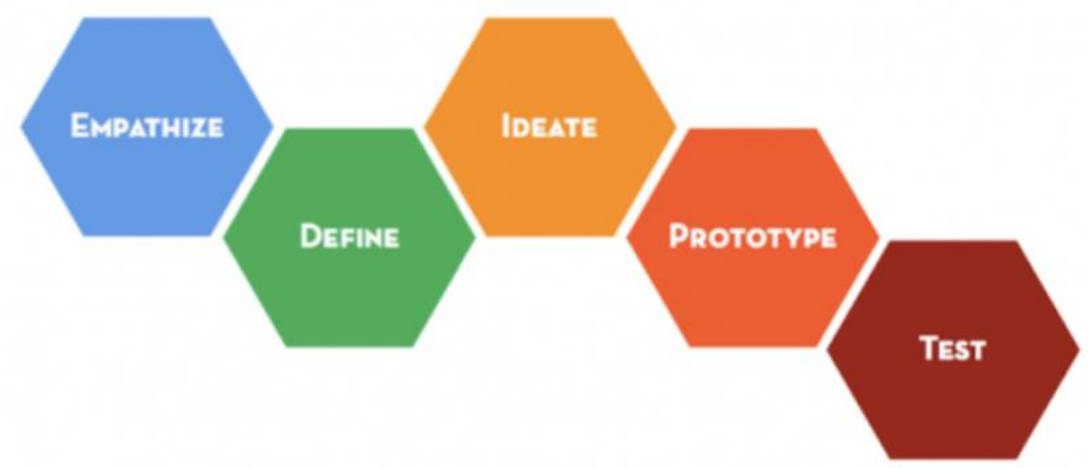

Gambar 1 Diagram Tahapan Metode Desain Thingking

\section{Hasil dan Pembahasan} Empathize

Hasil dan Pembahasan berdasarkan dari tahapan-tahapan Design Thingking.

Pada tahapan ini adalah untuk mendapatkan informasi dasar dari permasalahan yang sedang dikaji. Langkah-langkah pada tahapan ini adalah mengumpulkan informasi-informasi 
yang sedang dikaji serta dianalisis dengan tujuan agar mendapatkan persepsi, dan posibilitas yang akan dijadikan rujukan ke tahapan define.

Pada tahapan ini untuk mendapatkan informasi dasar dari permasalahan mahasiswa dalam mendapatakan informasi-informasi akademik adalah dengan mengadakan Focus Grup Discussion (FGD) bersama beberapa perwakilan mahasiswa dari masing-masing kelas. FGD dilakukan pada salah satu ruang pembelajaran Program Studi D-III Desain Komunikasi Visual di kampus dua Politeknik Harapan Bersama. Pada pelaksanaannya moderator langsung menanyakan kepada grup terkait dengan permasalahan dalam penyebaran informasi akademik prodi, serta menanyakan informasi-informasi apa saja yang mereka ingin dapatkan dari prodi.

Moderator menampung semua masukan dari peserta FGD yang akan dijadikan pertimbangan-pertimbangan terkati dengan konten yang akan dimunculkan di media informasi yang akan dibuat. Hasil dari FGD yang dapat disimpulkan adalah sebagai berikut : 1). Mereka sepakat agar ada media untuk dapat melihat/mengunduh jadwal perkuliahan dan agendaagenda akademik lainnya, seperti informasi libur, UTS, UAS, seminar, berita terkait kegiatan dari kampus ataupun prodi. 2). Mereka sepakat agar ada media untuk dapat mengetahui informasiinformasi seputar kelimuan DKV, baik artikel ilmiah maupun perkembangan seputar keilmuan DKV. 3). Mereka sepakat agar ada media untuk menampilkan karya-karya mereka dari tugas perkuliahan atau sejenisnya. 4). Mereka sepakat agar ada media untuk live streaming, barangkali ada dosen yang akan mengadakan perkuliahan jarak jauh karena berhalangan hadir di tempat. 5). Mereka sepakat agar ada media untuk menginformasikan kegiatan-kegiatan mahasiswa, seperti himaprodi dan sejenisnya. Selain dari Hasil dari FGD bersama perwakilan mahasiswa pada masing-masing kelas, juga mendapatkan beberapa masukan dari pihak prodi terkait dengan informasi-informasi prodi yang akan ditampilkan sebagai profil Program Studi DKV Politeknik Harapan Bersama Tegal.

Define

Langkah-langkah pada tahap ini adalah mencoba menerapkan konsep umum dari media website terhadap hasil empathize. Dalam hal ini adalah membuat kelompok menu atau submenu perintah yang akan menampilkan informasi-informasi sejenis dari FGD serta masukan dari prodi dan menghasilkan skema kerangka alur dari media website Prodi DKV Poltek Harapan Bersama Tegal.

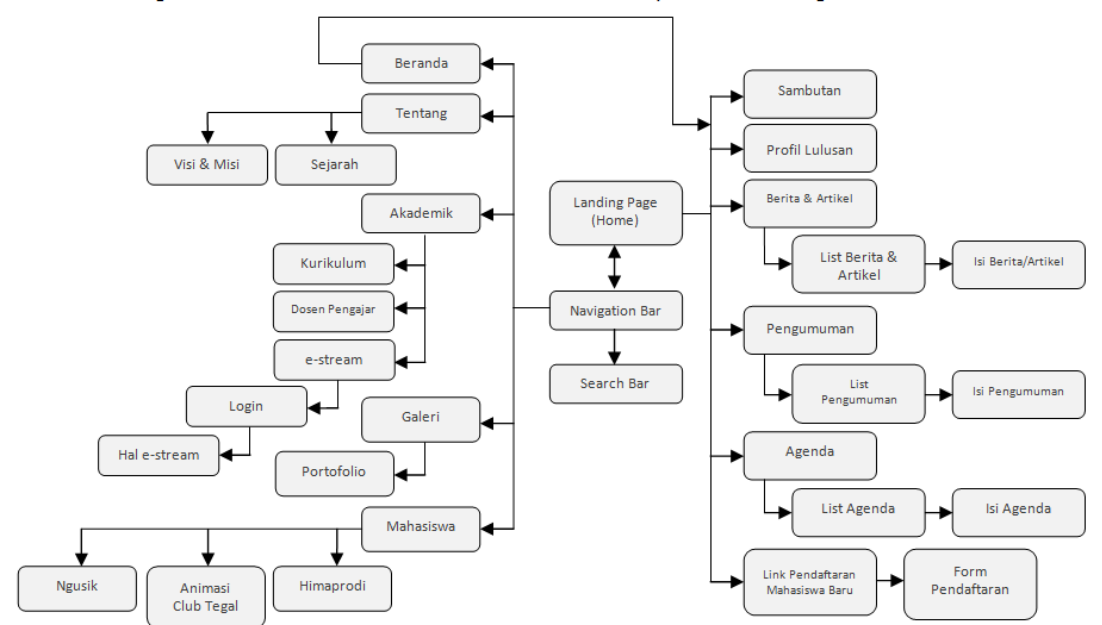

Gambar 2 Skema Kerangka Alur dari media website Prodi DKV Politeknik Harapan Bersama Tegal 
Ideate

Pada tahap ini yang berdasarkan rencana aksi dan peluang ini berfokus pada kuantitas ide dan berpotensi untuk menambahkan ide yang dihasilkan sebelumnya. Pada tahap ini juga proses perwujudan suatu ide berdasarkan (Yunus dalam Fakhruddin et al.). Yunus menjelaskan bahwa dalam perancangan interface website terdapat beberapa objek desain yang menjadi komponen dan elemen dasar yang dapat menunjang tujuan utama website tersebut, komponen dan elemen yang dijelaskan adalah sebagai berikut :

\section{Tata Letak dan Penempatan}

Layout atau tata letak digunakan dalam sebuah rancangan website dengan tujuan untuk dapat membuat elemen visual yang digunakan menjadi lebih komunikatif sehingga dapat mempermudah audiens untuk menerima informasi yang disajikan di dalamnya (Yunus dalam Fakhruddin et al.). Penempatan dan tata letak yang baik dapat mempermudah menjelaskan hubungan antara elemen visual yang digunakan pada sebuah interface. Konsep layout yang digunakan dalam perancangan website profil DKV adalah menerapkan konsep magazine style. Llayout magazine style menurut Ford adalah konsep layout website yang digunakan untuk menampilkan berbagai macam informasi atau berita, layout magazine style memberikan efek penceritaan (storytelling) yang kompleks. Dengan menggunakan konsep layout magazine style pada website prodi DKV diharapkan dapat memberikan banyak informasi akademik prodi maupun informasi kampus.

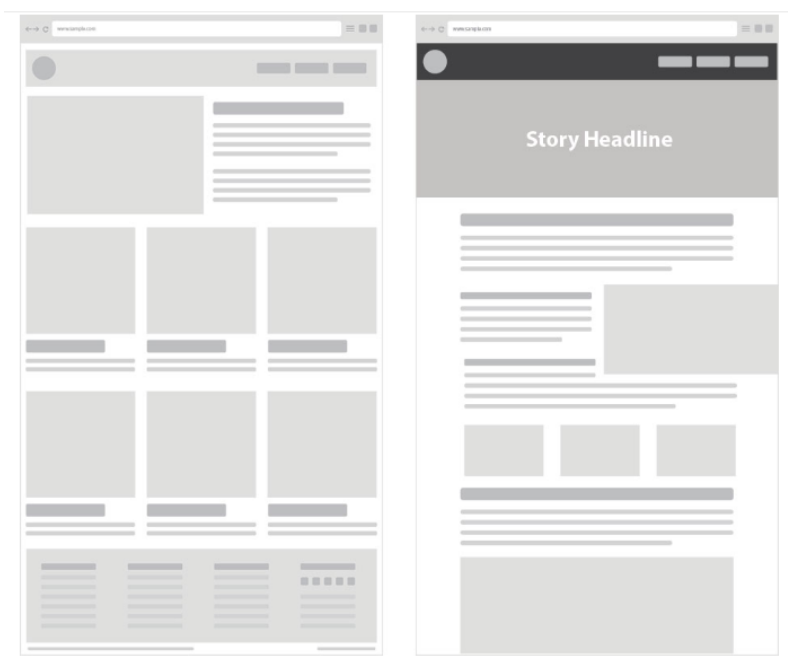

Gambar 3 Layout Magazine Style

\section{Bentuk dan Ukuran}

Penyesuaian elemen visual yang terdapat pada suatu interface terhadap ukuran perangkat pengguna dapat membantu untuk mennunjukan elemen-elemen visual berdasarkan bobot fungsinya secara signifikan. Fakhruddin et al. menjelaskan bahwa penyesuaian bentuk maupun ukuran akan dapat membantu untuk memperjelas hirarki visual yang terdapat dalam interface sebuah platform secara signifikan.

Konsep bentuk dan ukuran dalam perancangan ini menggunakan konsep responsivness (Soverini), menurutnya responsiveness adalah kemampuan website/aplikasi untuk diakses melalui berbagai macam bentuk media (PC, smartphone, TV, dsb.). 
Warna

Dalam perancangan sebuah interface maupun website secara keseluruhan, warna dapat berguna untuk dapat menjangkau berbagai tujuan yang beragam (Fakhruddin et al.). Hal senada dijelaskan oleh Yunus bahwa secara tidak langsung penyajian warna dalam sebuah rancangan user interface dapat sangat berpengaruh untuk dapat membentuk user experience. Warna utama yang digunakan adalah Hijau Tosca (Green Tosca), Toska adalah warna yang tenang dan ramah, Sementara hijau toska merupakan perpaduan warna antara biru yang kehijau-hijauan dengan warna hijau lebih dominan. Menurut Cerrato secara psikologis hijau toska melambangkan kejernihan pemikiran dan komunikasi. Hijau Toska mewakili ketenangan, keseimbangan emosi, harmoni, idealisme, kreatifitas, inspirasi, ekspresi diri, semangat, kemandirian dan pemikiran positif. Warna hijau tosca juga cocok untuk pria dan wanita segala usia. Warna Hijau tosca juga sudah disahkan oleh yayasan Politeknik Harapan Bersama sebagai warna bendera dan identitas seragam Program Studi Desain Komunikasi Visual Politeknik Harapan Bersama Tegal. Untuk meminimalisasi terjadinya degradasi warna pada tiap monitor yang memiliki resolusi berbeda, maka penggunaan kode Hexadecimal dan kode RGB digunakan sebagai patokan.

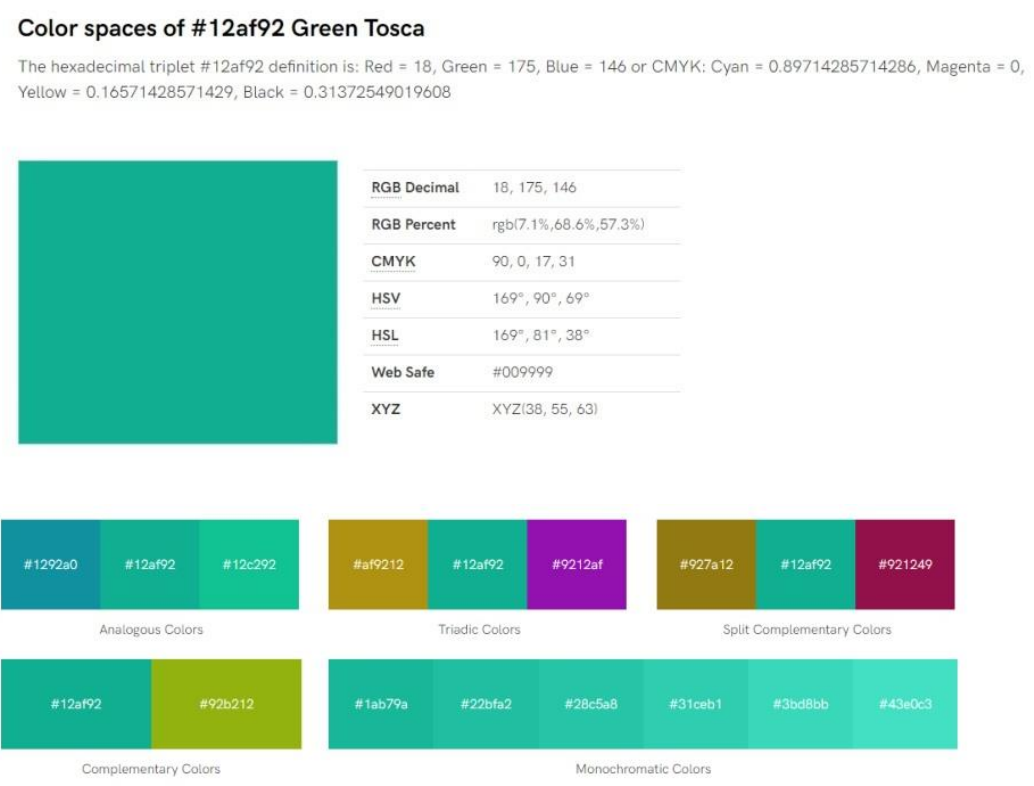

Gambar 4 Pallete warna Hijau Tosca

\section{Kontras}

Perancangan interface mempertimbangkan value dan mengevaluasi kontras dengan cara memangkas value kontras pada elemen-elemen tertentu akan menjadi hal yang sangat penting bagi efisiensi dan optimalisasi pengoperasian sebuah platform (Fakhruddin et al.). Konsep kontras pada perancangan ini mencoba mengidentifikasi elemen-elemen pada interface agar pengguna dapat membedakan antara elemen yang penting dan kurang penting, sebagai contoh text button hijau tosca pada background button putih akan berubah warna ketika pointer/mouse mengenai button.

\section{Tekstur}

Pengertian tekstur dalam pembahasan perancangan sebuah interface adalah sebuah upaya untuk mengkomunikasikan cara pengoperasian yang tepat sebuah user interface dengan 
tujuan agar lebih mempermudah pengguna memahami fungsi elemen-elemen interface yang disediakan secara intuitif pada sebuah platform (Fadeyev dalam Fakhruddin et al.).

Dari pengertian ini kemudian mencoba untuk menerapkan penyampaian visual pada suatu elemen interface dengan perantara layar elektronik yang digunakan oleh masing-masing pengguna sehingga dapat memicu sebuah interaksi yang diinginkan melalui bantuan perangkat yang dapat memberikan proses input perintah seperti mouse, touchpad maupun touchscreen dan menambahkan konsep microinteraction pada beberapa elemen website. Seperti yang dijelaskan oleh Soverini (dalam Fakhruddin et al.) Microlnteractions dan Transtion yang bertujuan untuk mendorong keterlibatan pengguna dan menciptakan pengalaman yang baik oleh pengguna.

\section{Tipografi}

Tipografi termasuk salah satu elemen penting pada perancangan sebuah interface maupun platform. Prinsip tipografi yang dapat membantu seorang perancang dalam mengoptimalkan rancangannya adalah Legibility dan Readability (Yunus dalam Fakhruddin et al.). Yunus menjelaskan bahwa Legibility adalah tingkat kemudahan mata manusia dalam mengenali suatu karakter/huruf tanpa harus bersusah payah terlebih dahulu untuk menyadarinya, sedangkan Readability adalah tingkat kualitas keterbacaan dan kenyamanan serangkaian huruf yang digunakan sebagai medium penyampaian informasi dalam sebuah rancangan. Penggunaan tipografi pada perancangan website informasi program studi Desain Komunikasi Visual Politeknik Harapan Bersama Tegal menerapkan prinsip Legibility dan Readability dengan menggunakan font Roboto. Christian Robertson seorang desainer font roboto menjelaskan bahwa roboto memiliki kerangka mekanis dan sebagian besar bentuknya geometris. Hal ini menjelaskan bahwa font roboto mampu memberikan legibility dan readability yang sesuai pada sebuah website. Font roboto dikembangkan oleh google dan digunakan pada beberapa layanan google seperti Google+, Google Play, Youtube, Google Maps dan google penelusuran pada seluler.

\section{Roboto Aa Ee Rr Aa Ee Rr Confectionery abcdefghijklm nopqrstuvwxyz 0123456789}

Gambar 5 Typeface Roboto

\section{Prototype}

Pada tahap ini adalah sebuah rancangan awal suatu interface yang akan dibuat, prototype bertujuan untuk mendeteksi kesalahan atau kekurangan sebuah interface sejak dini dan memperoleh berbagai kemungkinan baru. Dari proses yang dilalui dalam tahapan empathize sebelumnya, didapatkan hasil kesimpulan mengenai berbagai informasi yang dibutuhkan oleh calon pengguna. informasi-informasi yang dibutuhkan akan dikelompokan berdasarkan ketegori 
yang sudah ditentukan. Perancangan prototype website menggunakan Adobe Experience Design (XD) versi 24.3.

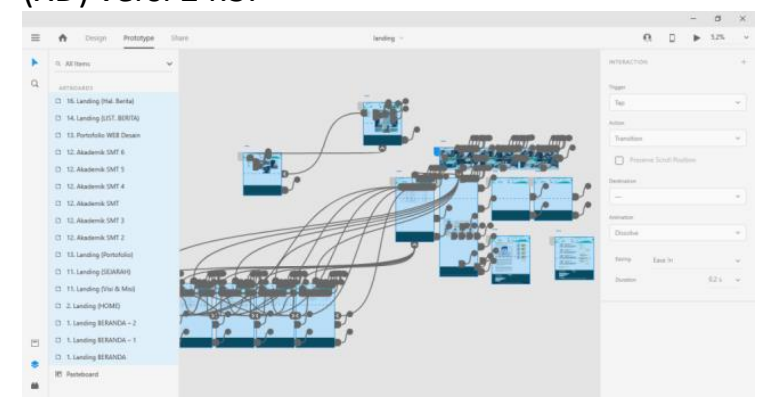

Gambar 6 Tampilan Desain prototype website informasi prodi di Adobe XD

Layout halaman website disesuaikan dengan tujuan dari perancangan yaitu untuk memberikan informasi akademik dan informasi lainnya yang sudah didapatkan dari FGD bersama beberapa mahasiswa perwakilan masing-masing kelas. Format desktop dipilih sebagai tampilan utama website untuk dapat memaksimalkan proses penyampaian informasi dan menggunakan orientasi horizontal, seperti bentuk website pada umumnya.

1. Halaman Pembuka

Sebelum masuk ke dalam halaman utama website pengguna akan diarahkan terlebih dahulu kepada halaman pembuka yang berfungsi sebagai intro. Pada halaman pembuka ini terdapat animasi yang berdurasi 10 detik yang kemudian akan mengarahkan pengguna menuju kepada halaman utama website (Halaman index).

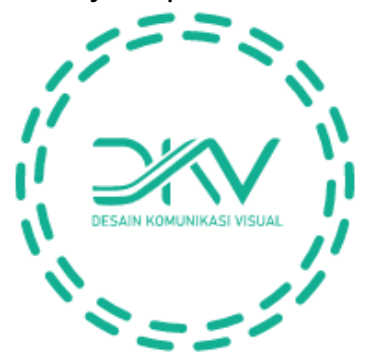

Gambar 7 Loading Page

2. Halaman Index (Utama)

Pada halaman index (utama) berisi tentang headline berita atau agenda akademik baik dari prodi maupun dari kampus. Beberapa interaksi pada halaman index adalah navigasi yang digunakan untuk melajutkan ke konten selanjutnya pada halaman index, navigasi ini bertujuan agar pengunjung dapat melihat-lihat headline yang ada pada halaman index. Interaksi pada navigasi ini adalah animasi smoothscroll serta parallax, animasi smoothscroll bertujuan agar pengunjung langsung diarahkan dengan pelan ke konten selanjutnya di halaman index dan animasi parallax untuk memunculkan konten website secara perlahan agar terlihat atraktif dan menarik. Selain berisi tentang headline, pada halaman ini juga terdapat informasi tentang sambutan, Profil Lulusan, Berita \& Artikel, Pengumuman, Agenda, Pendaftaran Mahasiswa Baru. Halaman ini juga terdapat navigasi untuk memilih halaman selanjutnya yang akan dituju. Halaman tersebut antara lain Tentang, Akademik, Galeri, Mahasiswa, Pencarian. 


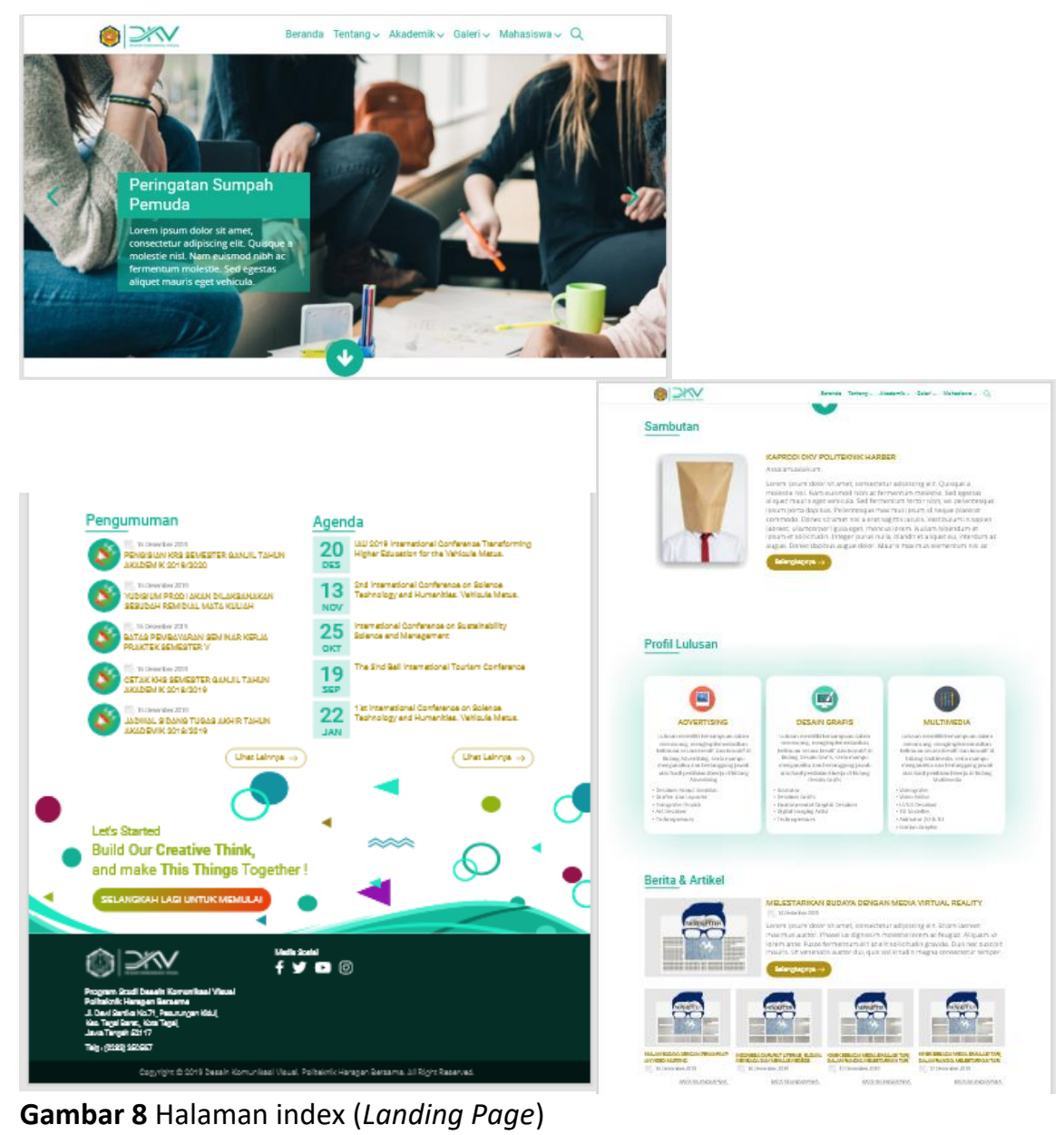

3. Halaman Tentang

Pada halaman 'tentang' akan ditampilkan informasi berupa deskripsi Visi, Misi dan Sejarah Berdirinya Program Studi Desain Komunikasi Visual Politeknik Harapan Bersama. Beberapa interaksi pada halaman 'tentang' adalah animasi smoothscroll serta parallax, animasi smoothscroll bertujuan agar pengunjung langsung diarahkan dengan pelan ke konten selanjutnya di halaman tentang dan animasi parallax untuk memunculkan konten website secara perlahan agar terlihat atraktif dan menarik. halaman ini juga terdapat navigasi untuk memilih halaman selanjutnya yang akan dituju. Halaman tersebut antara lain Beranda, Tentang, Akademik, Galeri, Mahasiswa, Pencarian. 


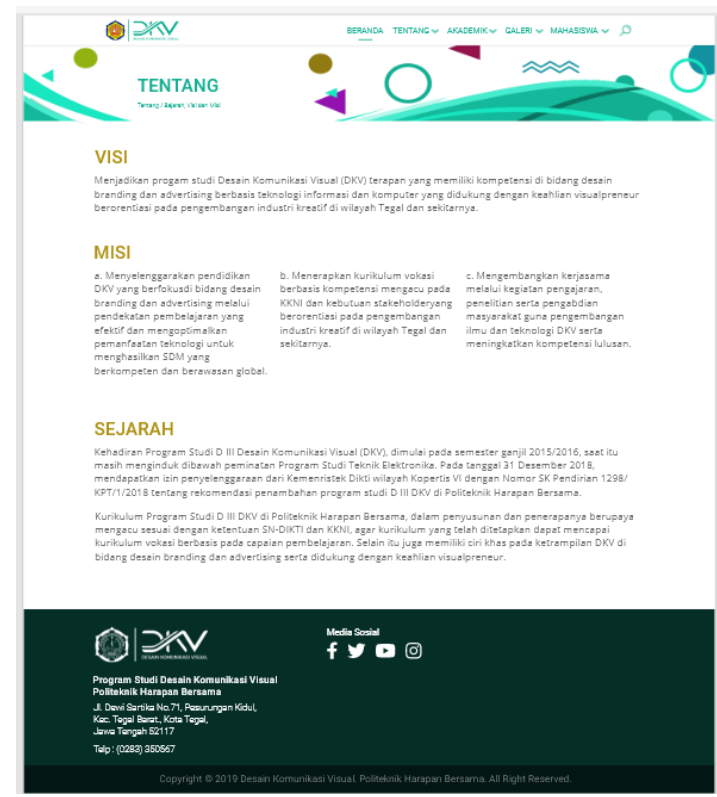

Gambar 9 Halaman Tentang

4. Halaman Akademik

Pada halaman 'Akademik' akan ditampilkan informasi berupa deskripsi kurikulum prodi dan daftar Dosen pengajar Program Studi Desain Komunikasi Visual Politeknik Harapan Bersama. Beberapa interaksi pada halaman 'Akademik' adalah animasi smoothscroll serta parallax, animasi smoothscroll bertujuan agar pengunjung langsung diarahkan dengan pelan ke konten selanjutnya di halaman Akademik dan animasi parallax untuk memunculkan konten website secara perlahan agar terlihat atraktif dan menarik. halaman ini juga terdapat navigasi untuk memilih halaman selanjutnya yang akan dituju. Halaman tersebut antara lain Beranda, Tentang, Akademik, Galeri, Mahasiswa, Pencarian.

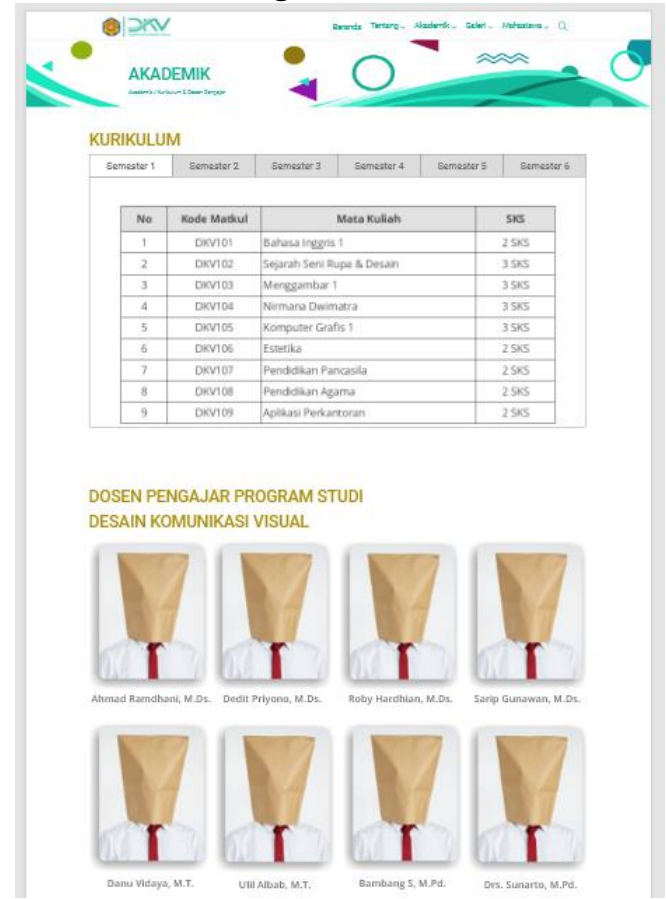

Gambar 10 Halaman Akademik 
5. Halaman Galeri

Pada halaman 'Galeri' akan ditampilkan informasi berupa portofolio tugas mahasiswa Program Studi Desain Komunikasi Visual Politeknik Harapan Bersama. Beberapa interaksi pada halaman 'Galeri' adalah animasi smoothscroll serta parallax, animasi smoothscroll bertujuan agar pengunjung langsung diarahkan dengan pelan ke konten selanjutnya di halaman Galeri dan animasi parallax untuk memunculkan konten website secara perlahan agar terlihat atraktif dan menarik. Selain itu animasi lightbox untuk menampilkan karya/gambar secara penuh. halaman ini juga terdapat navigasi untuk memilih halaman selanjutnya yang akan dituju. Halaman tersebut antara lain Beranda, Tentang, Akademik, Galeri, Mahasiswa, Pencarian.

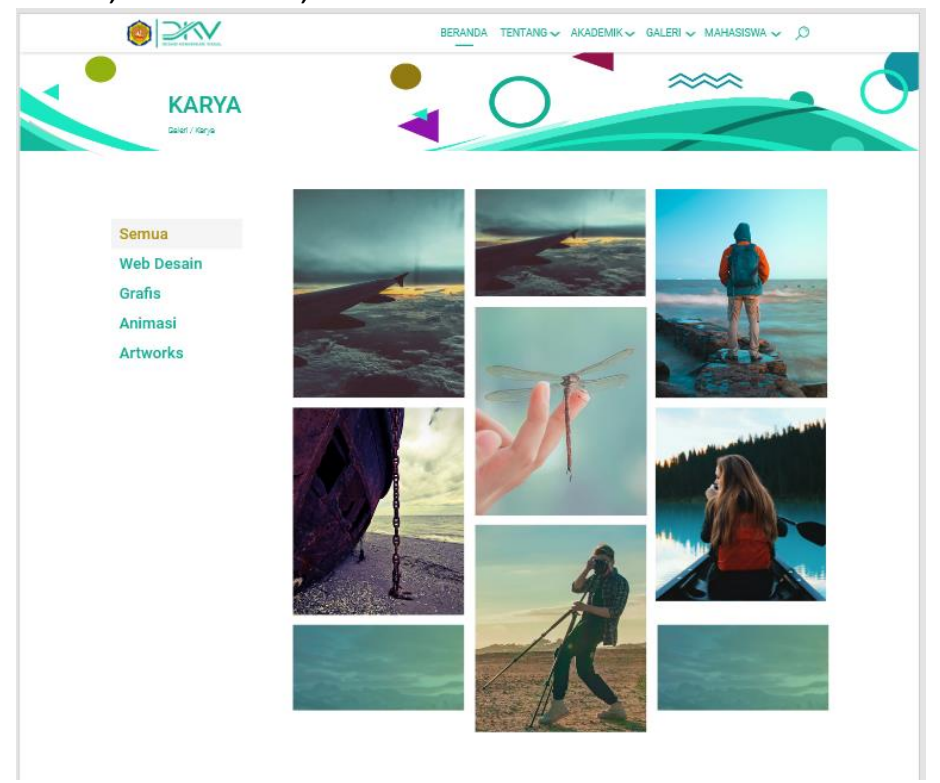

Gambar 11 Halaman Galeri

6. Halaman Search Navbar

Halaman seacrh pada navbar berfungi untuk melakukan pencarian informasi yang ada pada website prodi DKV Politeknik Harapan Bersama. Beberapa interaksi pada halaman ini adalah hover animasi dan smooth scroll.

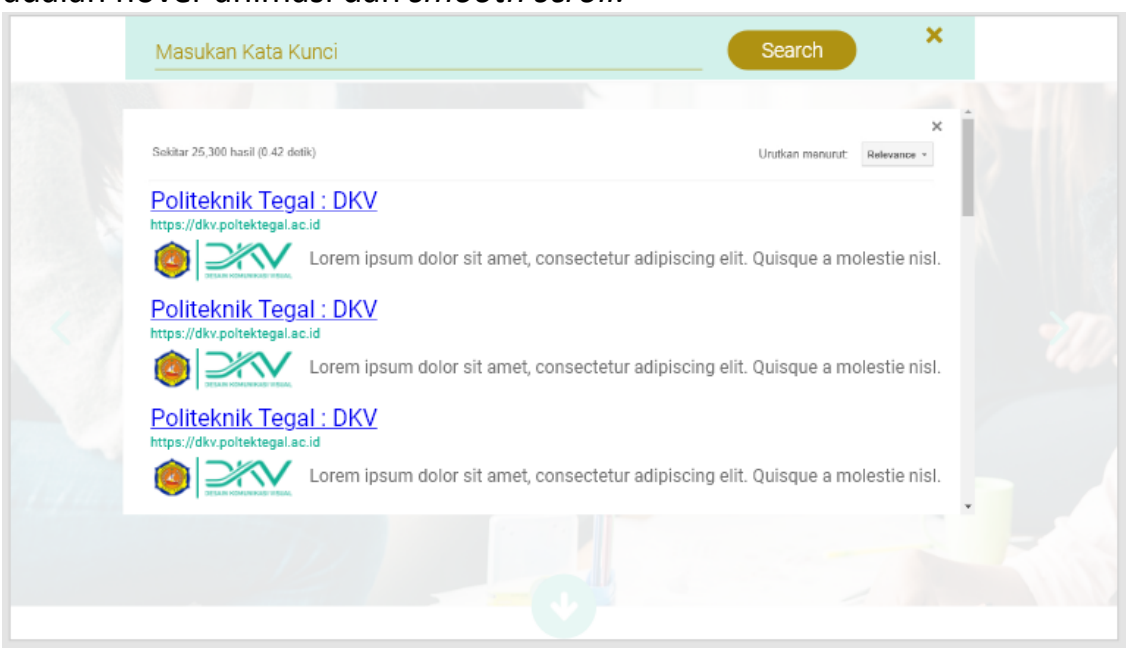

Gambar 12 Halaman Pencarian 
7. Halaman Berita \& Artikel

Pada halaman ini menampilkan informasi berita yang dipilih, Beberapa interaksi pada halaman 'Berita' adalah animasi smoothscroll serta parallax, animasi smoothscroll bertujuan agar pengunjung langsung diarahkan dengan pelan ke konten selanjutnya di halaman berita \& Artikel dan animasi parallax untuk memunculkan konten website secara perlahan agar terlihat atraktif dan menarik.

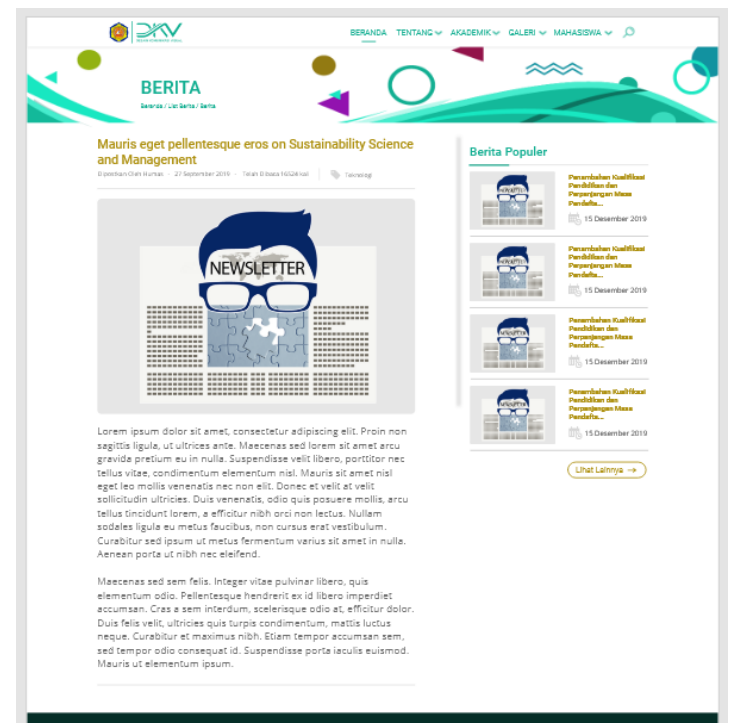

Gambar 13 Halaman Berita \& Artikel

8. Halaman List Berita \& Artikel

pada halaman ini menampilkan daftar berita yang pernah diunggah oleh admin, Beberapa interaksi pada halaman 'Berita' adalah animasi smoothscroll serta parallax, animasi smoothscroll bertujuan agar pengunjung langsung diarahkan dengan pelan ke konten selanjutnya di halaman list berita \& Artikel dan animasi parallax untuk memunculkan konten website secara perlahan agar terlihat atraktif dan menarik. Di halaman ini juga terdapat interaksi untuk melakukan pencarian berita berdasarkan kata kunci yang diinginkan.

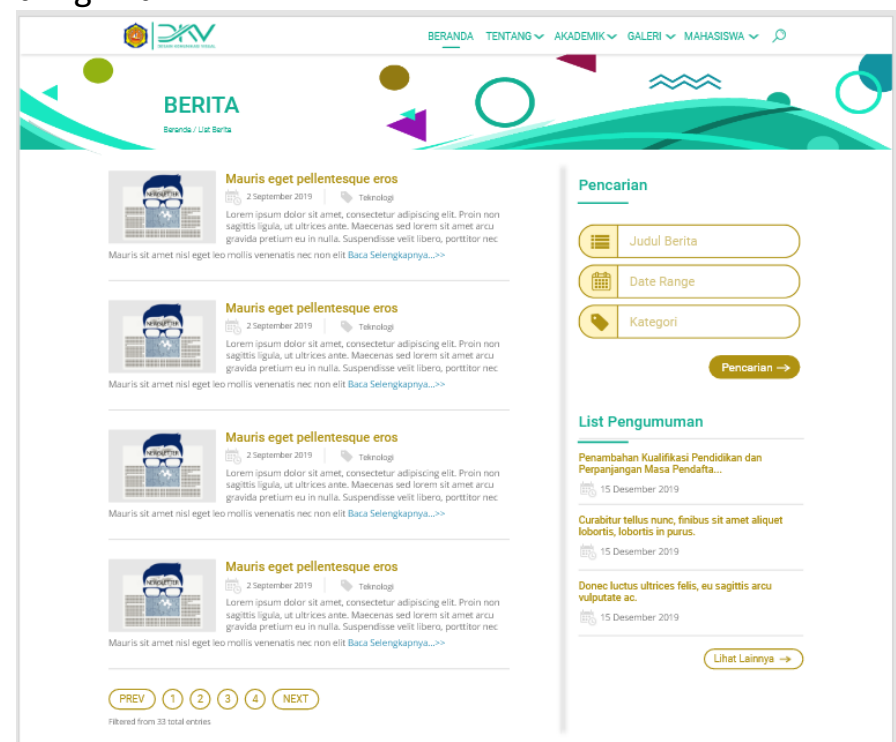

Gambar 14 Halaman List Berita \& Artikel 
9. Halaman Pengumuman

pada halaman ini menampilkan informasi pengumuman yang dipilih, Beberapa interaksi pada halaman 'Pengumuman' adalah animasi smoothscroll serta parallax, animasi smoothscroll bertujuan agar pengunjung langsung diarahkan dengan pelan ke konten selanjutnya di halaman pengumuman dan animasi parallax untuk memunculkan konten website secara perlahan agar terlihat atraktif dan menarik.

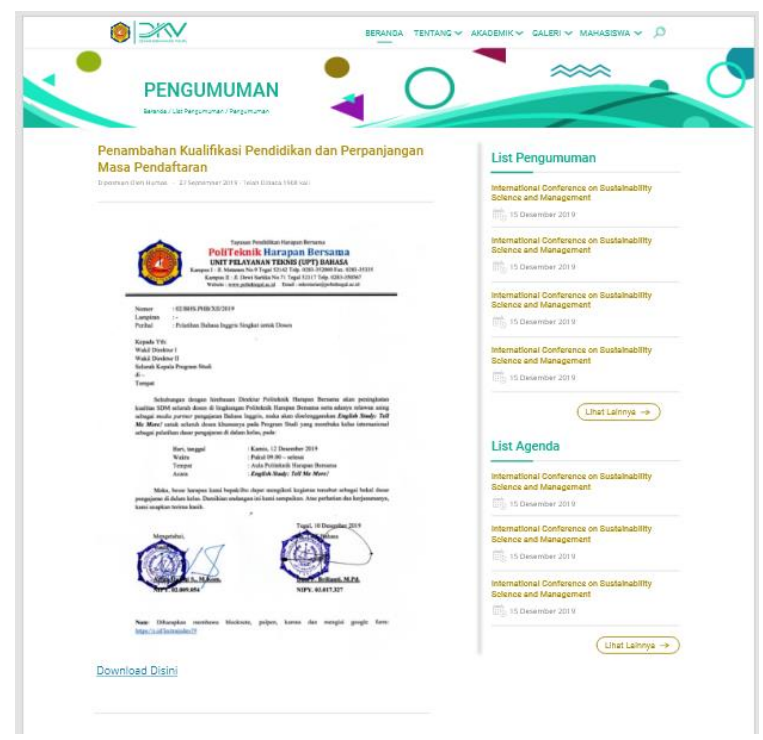

Gambar 15 Halaman Pengumuman

10. Halaman List Pengumuman

Pada halaman ini menampilkan daftar pengumuman yang diunggah oleh admin website, Beberapa interaksi pada halaman 'List Pengumuman' adalah animasi smoothscroll serta parallax, animasi smoothscroll bertujuan agar pengunjung langsung diarahkan dengan pelan ke konten selanjutnya di halaman daftar pengumuman dan animasi parallax untuk memunculkan konten website secara perlahan agar terlihat atraktif dan menarik.

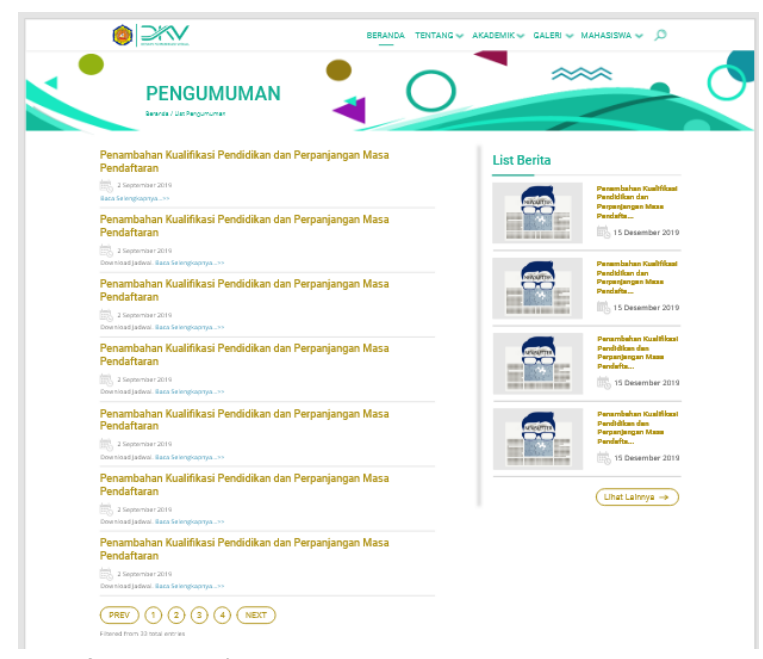

Gambar 16 Halaman List Pengumuman 


\section{Halaman Agenda}

pada halaman ini menampilkan informasi Agenda yang dipilih, Beberapa interaksi pada halaman 'Agenda' adalah animasi smoothscroll serta parallax, animasi smoothscroll bertujuan agar pengunjung langsung diarahkan dengan pelan ke konten selanjutnya di halaman agenda dan animasi parallax untuk memunculkan konten website secara perlahan agar terlihat atraktif dan menarik.

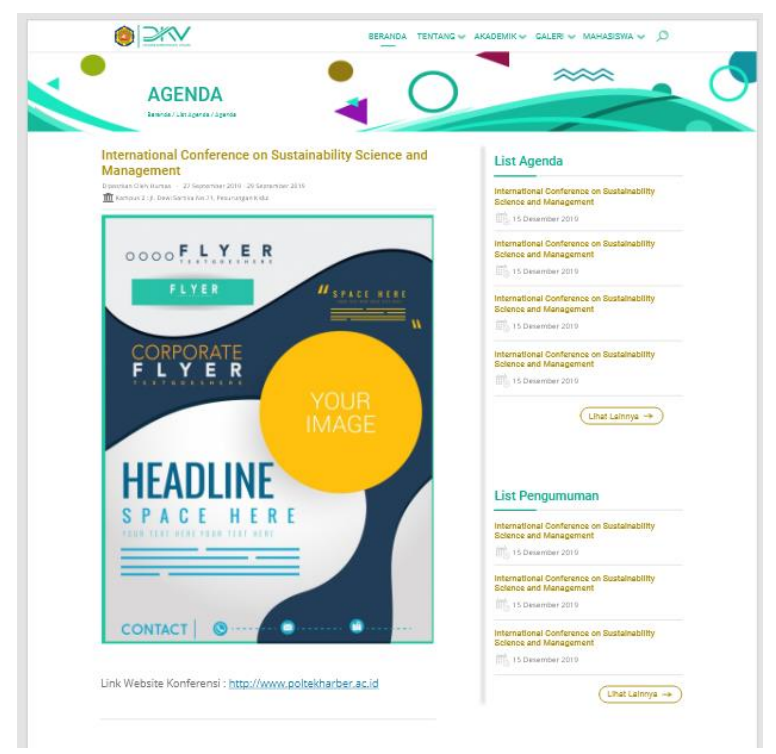

Gambar 17 Halaman Agenda

12. Halaman List Agenda

Pada halaman ini menampilkan daftar agenda yang diunggah oleh admin website, Beberapa interaksi pada halaman 'List Agenda' adalah animasi smoothscroll serta parallax, animasi smoothscroll bertujuan agar pengunjung langsung diarahkan dengan pelan ke konten selanjutnya di halaman list agenda dan animasi parallax untuk memunculkan konten website secara perlahan agar terlihat atraktif dan menarik. Di halaman ini juga terdapat interaksi untuk melakukan pencarian berita berdasarkan kata kunci yang diinginkan.

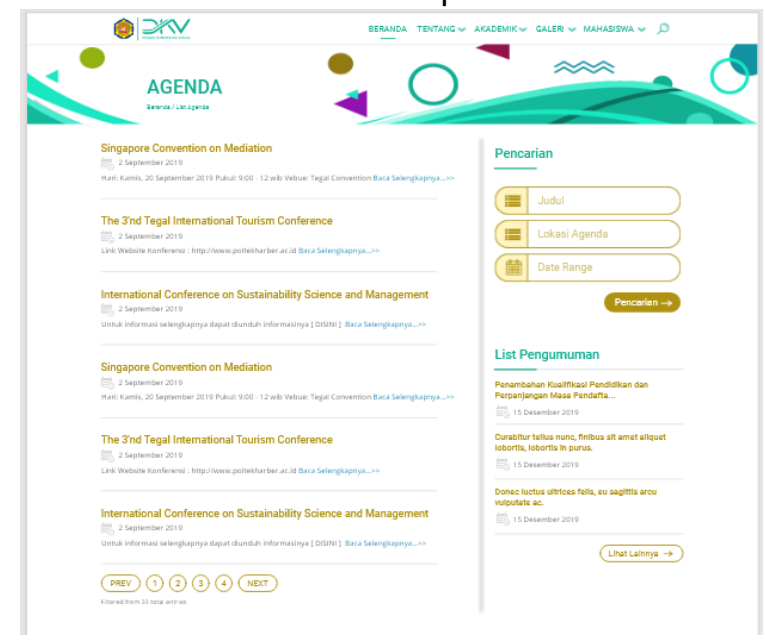

Gambar 18 Halaman List Agenda 
Test

Untuk mendapatkan respon terhadap hasil perancangan website informasi prodi DKV Politeknik Harapan Bersama, dilakukan uji coba website pada sejumlah responden yang sesuai dengan sasaran pengguna yaitu mahasiswa prodi DKV Polteknik Harapan Bersama. Pengambilan responden dilakukan dengan teknik purposive sampling, jumlah target pengguna sebanyak 68 responden yang terdiri dari 59 laki-laki dan 9 perempuan.

Tabel 2. Daftar Responden

\begin{tabular}{|l|l|l|}
\hline No & Jenis Kelamin & Jumlah \\
\hline 1 & Laki-Laki & 59 \\
\hline 2 & Perempuan & 9 \\
\hline Total & 68 \\
\hline
\end{tabular}

Uji coba dilakukan dengan cara responden mencoba mengoperasikan website informasi prodi DKV Politeknik Harapan Bersama, kemudian mengisi kuisioner yang telah disiapkan. Kuisioner menggunakan pilihan alternatif jawaban menggunakan skala linkert. Penggunaan skala linkert dipakai untuk mengetahui kecenderungan pilihan jawaban apakah sudah sesuai atau masih diperlukan perbaikan. skor nilai skala linkert dimulai dari skor tertinggi sampai dengan skor terendah, nilai skor jawaban adalah lima, empat, tiga, dua, satu yang disesuaikan dengan urutan pilihan jawaban Sangat Setuju, Setuju, Netral, Tidak Setuju, Sangat Tidak Setuju. Urutan pilihan jawaban dengan nilai skor dapat dilihat pada table di bawah ini.

Tabel 3. Pilihan Jawaban Skala Linkert

\begin{tabular}{|c|l|}
\hline Skor Nilai & \multicolumn{1}{|c|}{ Pilihan Jawaban } \\
\hline 5 & Sangat Setuju \\
\hline 4 & Setuju \\
\hline 3 & Netral \\
\hline 2 & Tidak Setuju \\
\hline 1 & Sangat Tidak Setuju \\
\hline
\end{tabular}

Jumlah skor dari jawaban-jawaban responden selanjutnya dianalisis menggunakan teknik analisis presentase dengan rumus perhitungannya sebagai berikut :

$$
\begin{array}{ll}
\mathbf{P}=\frac{\sum \boldsymbol{X}}{\sum \boldsymbol{X} \boldsymbol{i}} \boldsymbol{\mathbf { 1 0 0 }} \% & \\
\text { Keterangan : } & \\
\mathrm{P} & \text { : Presentase } \\
\sum X & \text { : Jumlah Skor Peniliaian } \\
\sum X i & \text { : Jumlah Skor Tertiggi } \\
100 \% & : \text { Konstanta }
\end{array}
$$

Setelah mendapatkan hasil jumlah skor jawaban dari responden, selanjutnya adalah membuat analisis presentase untuk menentukan kategori tinggi, sedang dan rendah dalam bentuk table statistik distributif. Dalam kategori skor dapat dilihat pada tabel 4.3. 
Tabel 4. Interval Nilai

\begin{tabular}{|c|l|}
\hline Interval Nilai & \multicolumn{1}{|c|}{ Kriteria } \\
\hline $0 \%-19,99 \%$ & Sangat Tidak Setuju/Baik \\
\hline $20 \%-39,99 \%$ & Tidak Setuju/Baik \\
\hline $40 \%-59,99 \%$ & Netral \\
\hline $60 \%-79,99 \%$ & Setuju/Baik \\
\hline $80 \%-100 \%$ & Sangat Setuju/Baik \\
\hline
\end{tabular}

Ada tiga aspek respon yang akan ditanyakan setelah responden mengoperasikan prototype website informasi prodi DKV Politeknik Harapan Bersama tegal. 1) Aspek konten, Organisasi dan keterbacaan, 2) Aspek Navigasi dan Tautan, 3) Aspek Visual (User interface).

1. Aspek Konten, Organisasi dan Keterbacaan

Pertanyaan-pertanyaan pada aspek ini bertujuan untuk mengetahui bagaimana tanggapan responden terhadap konten, organisasi konten (Menu atau Submenu) dan keterbacaan konten. Ada lima pernyataan yang diajukan kepada responden.

Tabel 5 Pernyataan Aspek Konten dan Organisasi

\begin{tabular}{|c|l|}
\hline NO & \multicolumn{1}{|c|}{ PERNYATAAN } \\
\hline 1 & Saya dapat dengan mudah menemukan informasi yang saya inginkan di website ini \\
\hline 2 & $\begin{array}{l}\text { konten yang disajikan pada website ini sudah dikelompokan sesuai dengan masing-masing } \\
\text { Kriteria dengan baik. }\end{array}$ \\
\hline 3 & Membaca konten website ini sangat mudah/nyaman. \\
\hline 4 & $\begin{array}{l}\text { saya merasa nyaman dan dan terbiasa dengan bahasa dan perintah yang digunakan di } \\
\text { website ini. }\end{array}$ \\
\hline 5 & saya tidak perlu menggeser ke kanan dan ke kiri pada saat membaca konten website ini. \\
\hline
\end{tabular}

Berdasarkan hasil pengujian yang sudah dilakukan pada aspek ini, nilai tertinggi terdapat pada pernyataan terkait konten yang disajikan pada website ini sudah dikelompokan sesuai dengan masing-masing Kriteria dengan baik yaitu dengan presentase sebesar $80,29 \%$. Mengacu pada interval nilai yang sudah dibahas sebelumnya, maka pengelompokan konten website informasi prodi DKV masuk dalam kategori "Sangat Baik" dalam pengorganisasian (menu dan submenu) website informasi prodi. Sedangkan pernyataan lainnya masuk dalam kategori "Baik" dengan presentase 73,24\%, 74,41\%, $75,88 \%$ dan $75,88 \%$.

Secara keseluruhan bahwa konten dan pengorganisasian konten website prodi DKV Politeknik Harapan Bersama Tegal mendapatkan prosentase nilai total sebesar 75,94\%, yang artinya masuk dalam kategori "Baik".

2. Aspek Navigasi dan Tautan

Pertanyaan-pertanyaan pada aspek ini bertujuan untuk mengetahui bagaimana tanggapan responden terhadap navigasi dan tautan (link) yang disediakan pada website informasi prodi DKV Politeknik Harapan Tegal. Ada empat pernyataan yang diajukan kepada responden.

Tabel 6. Pernyataan Aspek Navigasi dan Tautan

\begin{tabular}{|c|c|}
\hline NO & PERNYATAAN \\
\hline 1 & Saya dapat dengan mudah mengetahui posisi saya pada saat saya browsing website ini. \\
\hline
\end{tabular}




\begin{tabular}{|c|l|}
\hline 2 & $\begin{array}{l}\text { website ini memberikan isyarat dan tautan untuk saya mendapatkan informasi yang } \\
\text { diinginkan.. }\end{array}$ \\
\hline 3 & $\begin{array}{l}\text { sangat mudah untuk berpindah-pindah konten di website ini dengan menggunakan tautan } \\
\text { atau tombol kembali pada website }\end{array}$ \\
\hline 4 & $\begin{array}{l}\text { penempatan tautan atau menu pada website sudah sesuai dan saya dapat mengenali } \\
\text { dengan mudah }\end{array}$ \\
\hline
\end{tabular}

Berdasarkan hasil pengujian yang sudah dilakukan pada aspek ini, yang mendapatkan kategori "Sangat Baik" adalah Membaca konten website ini sangat mudah/nyaman dengan mendapatkan prosentase nilai sebesar $81,76 \%$ dan pernyataan saya dapat dengan mudah mengetahui posisi saya pada saat saya browsing website ini dengan prosentase nilai sebesar $80,29 \%$. Sedangkan pernyataan lainnya masuk dalam kategori "Baik" dengan prosentase nilai $72,35 \%$ dan $74,41 \%$.

Secara keseluruhan bahwa Aspek navigasi dan tautan (link) pada website prodi DKV Politeknik Harapan Bersama Tegal mendapatkan prosentase nilai total sebesar $77,21 \%$, yang artinya masuk dalam kategori "Baik".

\section{Aspek Visual (User Interface)}

Pertanyaan-pertanyaan pada aspek ini bertujuan untuk mengetahui bagaimana tanggapan responden terhadap tampilan yang disediakan pada website informasi prodi DKV Politeknik Harapan Tegal. Ada lima pernyataan yang diajukan kepada responden.

Tabel 7 Pernyataan Aspek Visual

\begin{tabular}{|c|l|}
\hline NO & \multicolumn{1}{c|}{ PERNYATAAN } \\
\hline 1 & Tampilan website ini sangat atraktif dan menarik \\
\hline 2 & saya sangat nyaman dengan warna yang digunakan pada website ini \\
\hline 3 & $\begin{array}{l}\text { konten yang ada pada website ini tidak menggangu saya, seperti banyak menggeser ke } \\
\text { kanan ke kiri atau text yang berkedip-kedip (warna-warni) dan animasi konten/text yang } \\
\text { berulang-ulang. }\end{array}$ \\
\hline 4 & tampilan website ini sudah konsisten dan menarik \\
\hline 5 & desain website ini sudah nyaman dan sangat mudah untuk dipahami. \\
\hline
\end{tabular}

Berdasarkan hasil pengujian yang sudah dilakukan pada aspek ini, yang mendapatkan kategori "Sangat Baik" adalah Tampilan website ini sangat atraktif dan menarik dengan mendapatkan prosentase nilai sebesar $81,18 \%$ dan pernyataan tampilan website ini sudah konsisten dengan prosentase nilai sebesar $80,59 \%$. Sedangkan pernyataan lainnya masuk dalam kategori "Baik" dengan prosentase nilai 73,82\%, 78,53\% dan 74,41\%. Secara keseluruhan bahwa Aspek visual (User Interface) pada website prodi DKV Politeknik Harapan Bersama Tegal mendapatkan prosentase nilai total sebesar $77,71 \%$, yang artinya masuk dalam kategori "Baik".

\section{Simpulan}

Berdasarkan hasil uji coba prototyping yang telah dilakukan, secara keseluruhan website informasi prodi DKV Politeknik Harapan Bersama dapat digunakan sebagai media alternative untuk memberikan informasi akademik prodi DKV ataupun informasi kampus Politeknik Harapan Bersama Tegal dan juga sebagai informasi berita atau artikel ilmiah terkait keilmuan 
Desain Komunikasi Visual (DKV) maupun sebagai tempat mahasiswa untuk menampilkan karyakarya yang telah dibuat selama masa studi di prodi DKV Politeknik Tegal. Penggunaan teknik parallax dan smoothscroll ataupun microinteraction yang terdapat pada navigasi atau tautan prototyping website ini juga dapat menambah ketertarikan pengguna, sehingga website tersebut menjadi lebih atraktif dan interaktif. Dengan adanya teknik prototyping ini, maka kreatifitas web desainer dalam membuat suatu tampilan dasar (User Interface sebuah website) tanpa harus ke scripting langsung. Hal yang perlu diperhatikan pada prototyping website adalah desainer harus mengetahui harus mengetahui animasi-animasi yang disediakan untuk scripting website (html, css dan javascript), agar nantinya programmer tidak mengalami kesulitan dalam perancangan scripting website prototype tersebut.

\section{DAFTAR PUSTAKA}

Batchu, Vamsi. "Micro-Interactions: Why, When and How to Use Them to Improve the User Experience." 2018, https://uxdesign.cc/micro-interactions-why-when-and-how-to-usethem-to-boost-the-ux-17094b3baaa0.

Beaird, Jason. The Principles of Beautiful Web Design. 2nd edition, SitePoint Pty. Limited, 2010.

Cerrato, Herman. "The Meaning of Colors." 2013, http://hermancerrato.com/graphicdesign/images/color-images/the-meaning-of-colors-book.pdf.

Fakhruddin, Dimas et al. "Pengembangan Desain Informasi Dan Pembelajaran Aksara Jawa Melalui Media Website." ANDHARUPA: Jurnal Desain Komunikasi Visual \& Multimedia, vol. 5, no. 01, 2019, pp. 1-23, doi:https://doi.org/10.33633/andharupa.v5i01.1990.

Ford, Chris. "Examples of Unique Website Layouts." 2017, https://webflow.com/blog/examplesof-unique-website-layouts.

Galitz, Wilbert O. The Essential Guide to User Interface Design: An Introduction to Gui Design Principles and Techniques. Second edition, Wiley Publishing, Inc., 2007.

Kuswanto, Heri. "Analisis Prinsip Layout and Composition Pada Web Design Perusahaan Pt. Bank Rakyat Indonesia, Tbk Dan Pt. Fif Group Berdasarkan Buku "the Principle of Beautifull Website Design by Jason Beaird"." Elinvo (Electronics, Informatics, and Vocational Education), vol. 2, no. 1, 2017, pp. 1-7, doi:https://doi.org/10.21831/elinvo.v2i1.14488.

Miller, Brian D. Above the Fold: Understanding the Principles of Successful Web Site Design. HOW Books, 2011.

Plattner, Hasso. "An Introduction to Design Thinking Process Guide." Institute of Design, 2010.

Rahmasari, Erisa Adyati and Dzuha Hening Yanuarsari. "Kajian Usability Dalam Konsep Dasar User Experience Pada Game "Abc Kids-Tracing and Phonics" Sebagai Media Edukasi Universal Untuk Anak." Desain Komunikasi Visual, Manajemen Desain dan Periklanan (Demandia), 2017, pp. 49-71, doi:https://doi.org/10.25124/demandia.v2i01.770. 
Razi, Aria Ar et al. "Penerapan Metode Design Thinking Pada Model Perancangan Ui/Ux Aplikasi Penanganan Laporan Kehilangan Dan Temuan Barang Tercecer." Desain Komunikasi Visual, Manajemen Desain dan Periklanan (Demandia), vol. 3, no. 02, 2018, pp. 219-237, doi:https://doi.org/10.25124/demandia.v3i02.1549.

Saffer, Dan. Designing for Interaction: Creating Smart Applications and Clever Devices (Voices That Matter). AIGA Design Press, 2007.

---. Microinteractions: Designing with Details. " O'Reilly Media, Inc.", 2013.

Soverini, Andrea. "Ux Project Checklist." 2018, https://uxchecklist.github.io/.

Yuhefizar. 10 Jam Menguasai Internet. Elex Media Komputindo, 2008. Jakarta: Elex Media Komputindo. 